\title{
Eric R. Smith, American Relief Aid and the Spanish Civil War (Columbia: University of Missouri Press, 2013). 208 pp. $\$ 60.00$ Hardcover.
}

We know a lot about the Spanish Civil War, but new topics and perspectives continue to appear. It is an amazing ongoing process given that Spain in 1936, and today, is a relatively minor country. Obviously what makes the war so important is not so much what happened to Spain or the Spaniards but the conflict's meaning. There was, and there is still, a battle for minds in which taking a position on the Spanish war is making a political statement about both the realities of the home country and the kind of world the we want. This rather brief book, containing only 127 pages of text, fully belongs to this tradition. And the story it tells is just short of fascinating.

There is a much liked and proclaimed American self-perception of their country as being a beacon of freedom. This is not the place to discuss this, but suffice it to say that this is not how the United States Government behaved towards Spain during most of the past century. The most notorious example happened in 1936 when, in contravention of international law, the Roosevelt administration put on the same legal footing both the legal Spanish Government of the democratic Republic and the rebels led by General Franco. Accordingly, the United States declared an embargo to Spain that prevented the Republic from obtaining the weapons it needed to defeat the rebellion. The United Kingdom and France, among others, did the same, while Fascist Italy and Nazi Germany were busy helping Franco's side. The United States' position was far from coherent, or honest, because powerful corporation such as Texaco, General Motors and Ford, also provided massive support to Franco. We know this story pretty well, but what we did not know until now is how ordinary Americans tried to help the Republic and the impediments they faced first and, soon afterwards, the price many of them paid for daring to dissent and to act.

This is the story that Eric Smith has narrated in his book. Sadly the text is too short - a product perhaps of the difficulties that the publisher has faced recently- and some of the contextual details and historical background for the Spanish side of the narrative are hazy at times. Nevertheless, this is a book that grows as the reader immerses oneself in its pages. In this sense, this reviewer found particularly interesting the last chapters. For example, the pages on the role of Catholics are subtle and informative as they dismount the myth of overwhelming Catholic support for Franco. What Smith shows instead is that a majority of Catholics were in sympathy towards the Republic, but an active minority, led by the high clergy, activist organizations such as the Knights of Columbus or public personalities such as the notorious radio preacher Father Charles Coughlin, actively took over the voice of Catholicism. Paradoxically, these pro-Franco advocates often argued that the rebel general was a defender of 
democracy and Spain's only hope for peace. Father Coughlin, for example, described the tyrant in early 1939 as "a rebel for Christ, a rebel for humanity's sake."(83)

Another interesting topic of this book is the fate of those activists who tried to help the beleaguered Spanish people, particularly those on the Republican side. During the war, they often suffered harassment and pressure from officials and active pro-Franco militants, the latter often counting on the complicity of the authorities. But there was a more sinister and long-lasting side to their story, which is intertwined with a major topic in modern American history: anti-Communism. Most of those who tried to help Republican Spain were not Communists, but many were. That was enough to taint, at least in the eyes of many powerful entities and individuals, the whole movement. And that turned out to be a stigma that, after World War Two, many honest, hard working and generous Americans had to bear in professional life when their past solidarity with the Republicans came back to haunt them as un-American, this is to say, moles and dupes of Moscow. The sad, yet revealing irony is that nobody who helped or advocated for Franco -Mussolini and Hitler's friend, America's enemies in World War Two- ever had to explain his or her actions or face retribution. Interesting enough, the same happened on the other side of the Iron Curtain, where the veterans of the International Brigades often paid, some with their lives, for the crime -in Stalin's eyes-of having dreamed of defeating Fascism in Spain.

In many senses, Eric Smith has launched new elements for a re-consideration of America's less than straightforward relationship with freedom in the 1930s, and afterwards. Examples of these elements include the fact that some of the same people who persecuted Americans for helping a beleaguered democratic regime would later be Franco's best friends during the long dictatorship. Elsewhere, during the Cold War, too many American officials, politicians and businessmen explained the Spanish dictatorship as a necessary reaction against a Communist threat in 1936. It was a convenient nonsense and a falsification of the past that again was not about Spain. The Spanish War, Franco and even the restored Spanish democracy have always had been analyzed though local American realities and concerns. The most remarkable exception to this selfinterested and self-congratulatory attitude continues to be that of those idealists who, during the Spanish Civil War, thought that Spain's cause was theirs.

Antonio Cazorla-Sanchez Trent University 